\title{
Evaluating Business Performance and Efficiency in the Medical Tourism: A Multi-criteria Approach
}

\author{
Veronika Čabinová \\ University of Prešov in Prešov, Prešov, Slovakia \\ Peter Gallo \\ University of Prešov in Prešov, Prešov, Slovakia \\ Petra Pártlová \\ Institute of Technology and Business in České Budějovice, České Budějovice, Czech Republic \\ Ján Dobrovič \\ Institute of Technology and Business in České Budějovice, České Budějovice, Czech Republic \\ Milan Stoch \\ University of Entrepreneurship and Law, Prague, Czech Republic
}

Received: 23 February 2021 Revision received: 20 April 2021 Accepted: 14 May 2021

\begin{abstract}
Measuring the performance and efficiency of the tourism enterprises is essential regarding the current pandemic situation. In such a context, improving their financial situation and competitive position also depend on the use of innovative multi-criteria evaluation models. The paper's main objective is to propose the newly designed Performance \& Efficiency model (P\&E model) for Slovak spa enterprises. Its structure consists of three dimensions - P\&E_I, P\&E_II, P\&E_III. The application of Confirmatory Factor Analysis validates 34 key performance ratios reflecting the financial situation of enterprises within the P\&E_I. In case of P\&E_II, the development of value-added dynamics is measured by using the Economic Value Added Momentum. Using the Data Envelopment Analysis, the level of enterprise efficiency is quantified (P\&E_III). The partial results of the dimensions are transformed using min-max normalization to the overall score ranging from 0 to 3 . Based on the results, a rating scale of all enterprises is carried out, and both their partial and overall positions are assessed through benchmarking. During the research $(2013$ - 2018), the best results are achieved for SE03 (Spa Bojnice, Inc.), SE21 (Specialised Spa Institute Marína, s.e.), and SE18 (Spa Horný Smokovec, Ltd.). The worstrated spa enterprises include SE14 (Natural Iodine Spa Č́̌́z, Inc.), SE09 (Spa Sliač, Inc.), and SE19 (Pieniny Resort, Ltd.). The proposed P\&E model is easily applicable to other tourism enterprises. The research as carried out enables deepening of knowledge concerning the multi-criteria evaluation and management concepts and helps enterprises overcome current unfavorable situations.
\end{abstract}

Key Words: Performance \& Efficiency model, spa enterprises, financial ratios, indicators, EVA Momentum, Data Envelopment Analysis.

JEL Classification: C51, C69, M21.

Reference: Čabinová, V., Gallo, P., Pártlová, P., Dobrovič, J. \& Stoch, M. (2021). Evaluating Business Performance and Efficiency in the Medical Tourism: A Multi-criteria Approach. Journal of Tourism and Services, 22(12), 198-221. doi: 10.29036/jots.v12i22.247

\section{Introduction}

Doing business in current global environment is challenging due to both the competitive pressure, supply increased over demand and globalization, and due to the pandemic situation (Mura, 


\section{JOURNAL OF TOURISM AND SERVICES}

Issue 12, volume 22, ISSN 1804-5650 (Online)

www.jots.cz

2020). The issue of business performance and efficiency analysis is currently being discussed more than in the past due to the constantly changing global business environment, also affecting the enterprises in tourism. As a result of the statistical methods, information technologies, and the growing interest of financial institutions and the enterprises themselves, however, there was a significant increase in the use of innovative models and business performance and efficiency measurement techniques in different economic sectors decade. As the often discussed industry, tourism rapidly developing in recent times and now largely affected by the pandemic situation is no exception. In many regions worldwide, tourism is one of the main sectors of the economy with high business activity (Gorochnaya et al., 2020).

The current tourism industry is affected by the corona virus crisis. Before the COVID-19 pandemic, travel and tourism was one of the most important sectors in the world economy (Kostynets, 2020). In order to increase the interest of tourists, attractions should be developed and the management should differentiate the enterprise from its competitors. However, it also requires a proactive approach of the tourism operators who must evaluate the available resources and develop an appropriate strategy to rely on and take advantage of (Nikšić et al., 2018). Such entities include also spa facilities with their infrastructure (accommodation units and food shops, treatment and leisure facilities, and auxiliary civic amenities) and they provide well-defined tourist functions in the territory that are able to attract and retain potential clients for a shorter or longer period of time (Herman et al., 2019). Increasingly, tourism and spa facilities are becoming the topic of a healthy lifestyle, and the clients are looking for them to improve their health. Such activities could be beneficial for a wide range of people including children, senior citizens and the people with disabilities. Even in the times of crisis, tourism has an indispensable place in the industries and needs special attention.

The research sample is based on the current demographic trends; as such trends have the ultimate and significant effect on the economic growth of countries. Due to that the authors to select a specific research sample - the spa enterprises that are a part of the public health care system. This system is currently under enormous pressure, mainly due to the aging population trend and rising health care costs. According to the medium variant of the UN forecast calculated for the countries of the European Union, almost $29 \%$ of the population is expected to be over 65 years of age by 2050 , offering an increase of possible clients. The spa industry fosters the development of employment in the region, contributes to the revenues of national budgets and regional budgets, helps create the active balance of trade, contributes to the national GDP, improves the global reputation of the state, and above all it improves the health of the population, reducing incapacity for work and delaying disability. It is therefore important to pay attention to such type of tourism and evaluate its current state and then focus on its support and development. Since the literary research in the theoretical part of the paper confirmed the assumption that no model has been provided in Slovakia by now (and even abroad) to evaluate the performance and efficiency of spa enterprises, the authors have decided to conduct the necessary research in this field. The paper deals with the field of tourism, which according to Fernando (2020); Kelic et al. (2020) is a global phenomenon able to create wealth for the world's countries; with a more detailed look on the spa enterprises.

The main objective of the paper is to propose a suitable structure of the newly designed Performance \& Efficiency model (P\&E model) for the spa enterprises in Slovakia and to encourage the development of multi-criteria evaluation and performance, efficiency and competitiveness management concepts in tourism practices.

The paper is structured as follows: following the introduction to the topic, literary research is presented in the second chapter concerning the performance and efficiency evaluation having a direct effect on the competitive position of the enterprises in the industry. The third chapter describes the research sample, the data and methods used, and the procedure for development and verification of the P\&E model created. In the fourth chapter, the authors present the results of practical application of the model on the sample of Slovak spa enterprises in 2013 - 2018, and the rating based on the analysis. 


\section{JOURNAL OF TOURISM AND SERVICES}

Issue 12, volume 22, ISSN 1804-5650 (Online)

www.jots.cz

The chapter is concluded by the discussion. In the last chapter, the most important results of the research are summarized. The chapter also outlines possible limits and encourages further research of the issue.

\section{Literature review}

Current enterprises, including the enterprises operating in the tourism industry, must respond to the ever-changing market situation, adapt to new changes and facilitate them, and improve their business activities, which is essential for the sustainability of their future growth (Ključnikov \& Belás, 2016; Balogová et al. 2020).

In this paper, the authors study the process of development of performance and efficiency evaluation model in tourism. Tourism is one of the important economic industries, optimizing the national economic structure and becoming an element of the sustainable development. The current pandemic situation does not favour the development of tourism; each country should thus try to help this industry continue to develop effectively, even in the current crisis. The tourism industry is based on many elements emphasizing its important nature. Processes of growing competition between destinations and uprisings the complexity of managing a tourism destination require a relation between all subjects of tourism (Van der Schyff, 2019; Kiryluk et al., 2020). By Draškovič et al. (2016), tourism affects both the economic aspects, and the social aspects of society. Tourism makes it possible to travel to diverse destinations and gain new knowledge, travel without any restrictive barriers, escape from everyday stereotypes, and acquire and extend knowledge independently. By Drossos \& Tsotsolas (2014), tourism consists of activities, services, and industries that deliver travel experience: transportation, accommodation, catering, entertainment, activities for individuals or groups as well as all tourism related service providers. The tourism market is currently undergoing big changes, tourism enterprises are getting into a critical situation, enjoyment of the tourists is massively limited and there are not many opportunities for it, especially during the Covid-19 pandemic (Androniceanu, 2020).

Thanks to its unusual nature and history, Slovakia has appropriate natural, historical and cultural prerequisites for the development of tourism. Its diverse regions offer a variety of activities. Spa is an activity in operation regardless the COVID-19 pandemic. The spa industry offers regeneration programmes for clients, both active and together with spa and treatment activities. The territory of Slovakia is abundant in many healing mineral and thermal (hot) springs. It also provides a source of curatives such as peloids, mud, peat and they have suitable climate. There are more than 1,200 mineral and thermal (hot) springs in Slovakia, thus Slovakia is ranked among the richest countries in this respect. The above described preconditions made it possible to establish many spa towns offering spa treatment, cultural and social events, and the Slovak spa industry has become known and used both by the domestic population, and in particular by foreign visitors. Slovak visitors visit spas mainly to "enjoy the water" that help in the treatment of many diseases, but spa towns also offer a variety of activities relaxation, exploring the vicinity and historical sites, hiking, and biking and walking around the spa resort (Šambronská et al., 2016 Šenková et al., 2016; Šíp, 2018; Tovmasyan, 2020).

In this paper, the authors discuss the model of performance and efficiency evaluation in tourism with a focus on spa enterprises, including literary research in economic terms. The actual term performance is understood (and therefore interpreted) in different ways at the theoretical as well as practical level of research. In the current global environment, business performance is best defined as achieving market success, being able to succeed in business competition and identify opportunities for further growth in an unstable business environment (Faltejsková et al., 2016; Kozubikova et al., 2019; Belás et al., 2020; Štefanová \& Balogová, 2019). Business performance is based on goals, which are the main factors that help formulate initiatives in planning, innovation, remuneration and improvement (Gallo \& Mihalčová, 2016; Sakdanuwatwong, 2020; Gruenbichler et al., 2021). The performance of an enterprise might be compared to measuring what a good-performing enterprise achieves over a period 


\section{JOURNAL OF TOURISM AND SERVICES}

Issue 12, volume 22, ISSN 1804-5650 (Online)

www.jots.cz

of time. By Choong (2013), the performance measurement is a form of improvement implementation which requires setting a certain goal so that it can be subsequently quantified and compared to the relevant reference benchmark. Thus business performance evaluation is a large and complicated process that combines key performance indicators (Popesko et al., 2016), contributing to value creation and adapting them to the current market conditions, helping to increase business performance and to maintain a continuous management process. As Blažková \& Dvouletý (2018) notice, the owners and the managers need to closely monitor the factors that affect the performance of the enterprise to maximize its market value and achieve long-term profitability. In this respect, Oladimeji et al. (2018) note that using the social networks and promoting innovations and the mutual cooperation of the enterprises in the industry foster their development, which also has a significant positive effect on the continuous growth of business performance.

Kotane (2015) states that as there are different approaches, models, tools and methods, there is no universal way of measuring business performance, meeting the needs of all stakeholders. However, researchers unanimously underline the need for systemic management of business performance and the need to focus on the right performance indicators and procedures that are adequately applicable and beneficial to specific users of performance analysis. By Narkunienè \& Ulbinaite (2018), despite the significant popularization of modern concepts, financial performance indicators are most often used to evaluate the financial health and performance of an enterprise. The potential of financial analysis for evaluating the financial health and performance of the enterprise is analysed, for example, by Sekhon \& Kathuria (2019); Eremina et al. (2019); Schwab et al. (2019) in their empirical studies. The long-term application of financial performance indicators has established a system of ratios, which is applied in practice by most of the enterprises - liquidity, activity, indebtedness, profitability, market value, productivity, cost, solvency and cash flow indicators. The ratio monitoring instead of total amounts in the financial statements is intended to achieve more meaningful results, more appropriate comparisons between different the sizes of the enterprises in different industries and in the particular enterprise.

The limitations of standard indicators are addressed by modern concepts and approaches to business performance evaluation, taking risk into account, working with the cost of capital, and examining the impact of inflation and based on economic profit, and cash flows of the enterprise (Haseeb et al., 2019). More and more attention is thus paid to the concepts and metrics not derived exclusively from the financial statements (Ključnikov et al., 2019). The Economic V alue Added indicator remains one of the most popular and modern financial metrics for evaluating financial performance, which reflects the value creation process. Such indicator shows whether the income in the analysed period is higher than the expected expenditure and cost of capital. As the value rises, the indicator reflects better achievements in performance, which increases the possibility of paying higher dividends and stock prices on the stock exchange (Bhasin, 2017). The EVA indicator and its various modifications are used in many empirical studies, in which their authors analyse its benefits, strengths and weaknesses, and barriers, and the applicability in practice in different countries together with its connection with other modern indicators and indices. Due to the limited scope of the paper, only a limited number of studies, worldwide are presented, such as Gupta, Sikarwar (2016); Strelnik et al. (2017); Grandson (2018); Shad et al. (2019); Zhang \& Aboud (2019).

Efficiency, among other main criteria for evaluating business performance, is one of the major goals of the implementation of corporate economic and financial activities (e. g. Dokulil et al., 2020). Business economic efficiency was first defined by Farrell (1957). He claims that it consists of two basic components, namely technical efficiency, reflecting the ability of an enterprise to produce the maximum output from the minimum quantity of inputs, and allocative efficiency, reflecting the ability of an enterprise to use the inputs in the optimal way with regard to their prices and manufacturing technology. Callender (2012) defines the efficiency as a purpose-driven process of satisfying the evergrowing needs of society at the maximum possible level. The more efficiently the enterprise can run, the more effective will be the realization of its production on national and world markets. Reaching 


\section{JOURNAL OF TOURISM AND SERVICES}

Issue 12, volume 22, ISSN 1804-5650 (Online)

www.jots.cz

higher efficiency can help the enterprise to implement its strategic activities better, or cheaper than competitors, which in turn will lead to a competitive advantage and increased performance. That is why the measurement and continuous monitoring of efficiency as well as the factors that can have a positive and negative effect on it is one of the preconditions for competitive success in business.

Evaluating the efficiency of production units is widely applied both in private and public sectors. Measuring the efficiency and especially the identification of possible inefficiency is a very important step to improve the competitiveness and the overall acting in competitive environment of the enterprises. Currently, there is a wide range of methods and procedures to measure the efficiency of production unit activities. Kumbhakar et al. (2015) present three basic approaches - using ratios, parametric methods(Stochastic Frontier Approach, Distribution Free Approach, Thick Frontier Analysis, Corrected Ordinary Least Squares), and non-parametric methods (Data Envelopment Analysis, Free Disposal Hull, Stochastic Data Envelopment Analysis - DEA). However, literature often mentions methods such as mathematical programming, econometrics, and a range of simulation methods for measuring (mostly economic) efficiency.

DEA is currently one of the most commonly used non-parametric methods to analyse the marginal efficiency (Stichhauerova \& Pelloneova, 2019); therefore, the authors of the paper include it in their P\&E model. As stated by Ruinan (2019), DEA does not assume technical inefficiency, where one of the effects of such neutrality is that no random error is taken into consideration when measuring efficiency. The idea of assessing technical efficiency can be traced back to the second half of the $20^{\text {th }}$ century, when Farrell (1957) developed a basic methodology for analysing technical efficiency of units. A few years later, Farrell's approach was modified for multiple outputs and formulated as a problem of linear programming by Charnes et al. (1978). Since the authors mentioned above introduced the DEA method, it has become a popular subject of research in many empirical studies; its popularity has been growing in recent years. The overview of empirical studies concerning DEA and its future development trend is discussed by e.g. Emrouznejad \& Yang (2018); Zhou et al. (2018); Ganesha et al. (2019), and Contreras (2020).

\section{Methods}

The main objective of the paper is to propose a suitable structure of the newly designed Performance \& Efficiency model (P\&E model) for the spa enterprises in Slovakia and to contribute to developing the concept of multi-criteria evaluation and management of business performance, efficiency, and competitiveness in tourism. Achieving the main objective of the paper is conditioned by achieving other sub-objectives specified in the following logical sequence:

- PC_1: Determine a suitable theoretical structure of the P\&E model - to create a suitable combination of ratios, methods, and models considering the important aspects of financial performance and efficiency of spa enterprises, based on available national and foreign professional literature.

- PC_2: Describe the methodology for calculating individual dimensions of the P\&E model - a prerequisite for this step is to examine the possibility of the application of financial performance ratios, methods, and models selected within PC_1 in Slovak business environment and include them in the calculation together with the specific characteristics of the analysed sample of the spa enterprises.

- PC_3: Application of the P\&E model in Slovak spa enterprises - to apply the P\&E model in the defined structure and specified method of calculation on real data of different Slovak spa enterprises in $2013-2017$.

- PC_4: Verify the suitability of the created P\&E model's structure - to identify and assess statistically significant relation between the overall average score of the P\&E model achieved by all the spa 


\section{JOURNAL OF TOURISM AND SERVICES}

Issue 12, volume 22, ISSN 1804-5650 (Online)

www.jots.cz

enterprises in the sample within the PC_3 and the overall score quantified in the same way using the data from 2018.

- PC_5: Interpret and summarize the results achieved - comprehensive summary of the most important results, the identification of the spa enterprises with the best and worst position in the industry.

\subsection{Research sample}

The research sample consists of Slovak spa enterprises, which are, given the current demographic development of the population, considered the main product line of tourism. There are only $30 \mathrm{spa}$ enterprises operating in Slovakia with the official licence of the Ministry of Health of the SR; the number thus could not be influenced in any way. However, this was not considered a reason for choosing a different group of enterprises; on the contrary, the authors tried to elaborate a unique study. The size of the research sample was thus not considered a difficulty; however the fact was considered in choosing the appropriate mathematical-statistical methods.

In the research part of the paper, the structure of the P\&E model is formulated on the basis of the data from 21 spa enterprises; nine enterprises are not included in the analysis due to their reporting of negative equity in the case of two spa enterprises and also due to the fact that several non-profit and public-benefit corporations operated in the area could not be included in the analysis due to specific features of their financing and legal framework of the Slovak Republic. The resulting research sample thus consisted of the following 21 spa enterprises: Spa Bardejov, Inc. (SE01), Horezza, Inc. (SE02), Spa Bojnice, Inc. (SE03), Spa Dudince, Inc. (SE04), Spa Lučivná, Inc. (SE05), Spa Lúčky, Inc. (SE06), Spa Nimnica, Inc. (SE07), Spa Nový Smokovec, Inc. (SE08), Spa Sliač, Inc. (SE09), Spa Štós, Inc. (SE10), Spa Trenčianske Teplice, Inc. (SE11), Spa Vyšné Ružbachy, Inc. (SE12), Thermal Spa, Inc. (SE13), Natural Iodine Spa Č́ž, Inc. (SE14), Slovak Thermal Spa Piešt’any, Inc. (SE15), Slovak Thermal Spa Rajecké Teplice, Inc. (SE16), Slovak Thermal Spa Turčianske Teplice, Inc. (SE17), Spa Horný Smokovec, Ltd. (SE18), Pieniny Resort, Ltd. (SE19), Slovthermae - Spa Diamond Dudince, s.e. (SE20), Specialised Spa Institute Marína, s.e. (SE21).

By the statistical classification of economic activities of the Statistical Office of the SR, Slovak spa enterprises are included in the section Q - Health and Social care, Division 89 - Health care and specific subclasses 86.909 - Other health care. In terms of the legal form, there are currently 18 jointstock companies, 3 limited liability companies, 3 public-benefit corporations, 2 state-owned enterprises, and 2 non-profit organizations operating in the field of providing spa care. Most of these spa enterprises are in national private ownership (64.29\%), 25\% are owned by the state, $7.14 \%$ are in foreign private ownership, and one enterprise is owned by associations, political parties, and churches.

\subsection{Data and methods}

The data for analyses was obtained from the financial statements and industry statistics of the spa enterprises provided by Data Spot, s.r.o. and CRIF - Slovak Credit Bureau, s.r.o. Within the quantification of the costs of equity, the data were obtained from the official website of the National Bank of Slovakia and internet databases of professor Damodaran. Additional information and nonfinancial information was provided mostly via e-mail by the marketing and human resources departments of individual Slovak spa enterprises. The data were subsequently processed in MS Excel. This software is used for all calculations of performance ratios and for the calculations of EVA

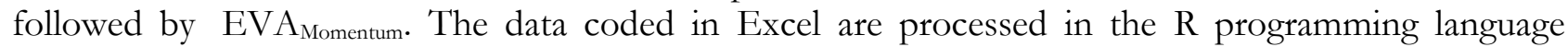
(version 3.6.1) within the application of mathematical-statistical methods. The efficiency of spa enterprises is calculated using DEA Solver (LV 8.0.).

In the processes of gathering and processing the information and data, basic methods of scientific research were used, such as analysis, synthesis, induction, deduction, comparison, description, 


\section{JOURNAL OF TOURISM AND SERVICES}

Issue 12, volume 22, ISSN 1804-5650 (Online)

www.jots.cz

abstraction, and analogy. For designing and subsequent verification of the P\&E model, confirmatory factor analysis, correlation analysis, Data Envelopment Analysis (DEA), modified Global Capital Asset

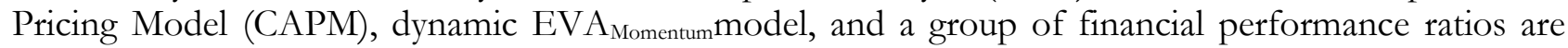
used. The results of the enterprises are compared with the results of their competitors using benchmarking.

\subsection{P\&E model construction process}

Figure 1 below shows a simple diagram of the P\&E model. It shall be noted that choosing the dimensions of the P\&E model is based on the findings published in professional literature, the common methods and the models related to the quantification of corporate efficiency and performance. The uniqueness of the P\&E model lies in interlinking the important aspects of evaluating corporate results into a more complex concept.

Figure 1. Design of structure and calculation of P\&E model's overall score

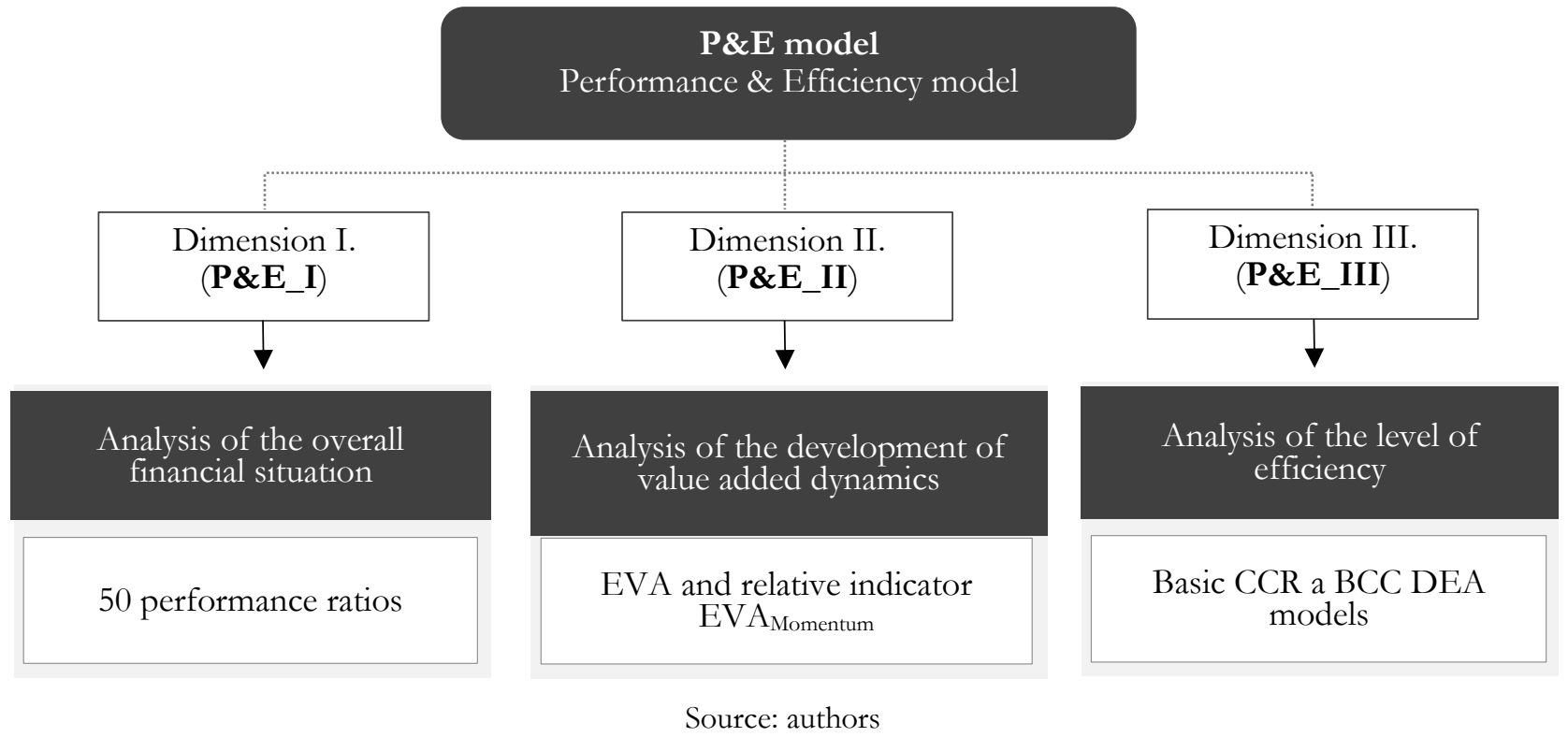

The text below presents a more detailed description of the calculation method for the P\&E dimensions forming its final structure, followed by the verification of the structure.

- Dimension P\&E_I

The first dimension of the P\&E model consists of the performance ratios, being necessary basis for evaluating the financial situation of the enterprises, as they enable getting a clear picture of the most important financial characteristics and identification of the areas requiring deeper analysis.

a) Calculation of selected groups of performance ratios

The results of literary research implied selection of 50 performance ratios evaluating all important fields of financial health and performance of enterprises (liquidity, activity, debt, profitability, cost efficiency, efficiency, and cash flow). The calculations are carried out for each enterprise (21 in total) for each year of the period $(2013-2018)$. The results are summarized and the overall development and situation in the industry is analysed.

b) Statistical processing of input data

Outliers in quantified performance ratios are identified using Hampel's test. By its results, the highest number of outliers is identified in the liquidity indicators, specifically Quick ratio (PL_F1). In absolute 


\section{JOURNAL OF TOURISM AND SERVICES}

Issue 12, volume 22, ISSN 1804-5650 (Online)

www.jots.cz

terms, a total of 358 extreme values are identified, which means that their average occurrence in each ratio in the sample amounts $6.82 \%$. The identified extreme values are removed and substituted appropriately, using the mice package of the $\mathrm{R}$ programming language intended for continuous, binary, and categorical variables, and performing the multiple imputation by chain equations.

c) Assessment of the suitability of internal factor structure of variables

Following the statistical processing of the data, the next step is the assessing the suitability of the internal factor structure of latent and manifest variables, and in searching for a structure of variables that would better capture the complexity of mutual relations of latent variables. In the original model, which included 50 performance ratios, not all of them achieved the required value of Average Variance Extracted (AVE) and Composite Reliability (CR) of 0.5 (0.7). For this reason, it is necessary to focus on problematic manifest variables using the achieved level of FL and then remove them. From the original number of 50 performance ratios, only 34 of them are confirmed using the CFA method.

d) Normalization of results to a uniform scale

The spa enterprise with the highest overall value of the ratio $\left(\mathrm{x}_{\max }\right)$ in comparison with other competitors is assigned the value 1 , while the enterprise with the lowest value $\left(\mathrm{x}_{\min }\right)$ is assigned the value 0 . The remaining values of the ratios are scaled according to relevant formulas. Each enterprise could obtain up to 34 scaled units (for each ratio). The results are recalculated in relation to the given base, thus providing another evaluation at the interval of $<0,1>$. Such quantified partial score within the first dimension of the P\&E model enables to evaluate the overall level of the financial health.

\section{- Dimension P\&E_II}

The EVA indicator and the $\mathrm{EVA}_{\text {Momentum }}$ applied relative indicator are considered an independent criterion for evaluating performance, in contrast to the performance ratios, EVA measures the economic profit of the enterprise, it analyses the creation of the shareholder value, market risks, and return requirements for the investors.

a) Calculation of cost of equity $\left(r_{e}\right)$

When determining the cost of equity, the CAPM model is used, as it represents the only theoretically based and also globally recognized method for calculating the discount rate of market valuation. In order to adapt the $r_{e}$ CAPM to the conditions of Slovak business environment as much as possible, the values of the variable $\mathrm{r}_{\text {eCAPM_SR1-Europe }}$ are chosen from the possible modifications. Using the given modification, the risk-free return $\left(\mathrm{r}_{\mathrm{f}}\right)$ is quantified on the basis of Slovak Republic ten-year government bonds. The values of capital market risk premium (ERP) and the country risk premium (CRP) are found on prof. Damodaran's website. The value of the coefficient $\beta_{\text {Levered }}$ (beta coefficient as a level of

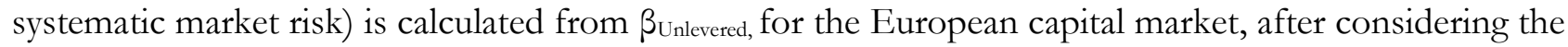
capital structure of the Slovak spa enterprises.

b) Normalization of results to a uniform scale

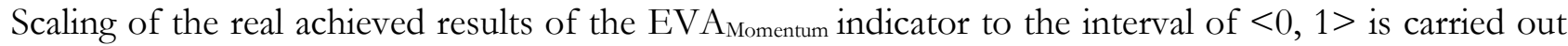
using min-max data normalization. The transformation of the values, however, was much easier compared to the first dimension of the P\&E model, since only one ratio is evaluated, the desired trend of which is a stable growth.

\section{- Dimension P\&E_III}

Within the $3^{\text {td }}$ dimension of the P\&E model, DEA method is applied to quantify the efficiency of the Slovak spa enterprises, based on determining technical efficiency of production units (a specific spa enterprise) on the basis of predefined inputs and outputs within the whole sample of considered homogeneous units (21 spa enterprises). As the spa enterprises are considered business entities and were not subject to any efficiency analysis previously, selecting a suitable DEA model (input/output oriented, assuming constant/variable returns to scale) is based on comparison with the results of available empirical studies in the hospitality and health care sectors.

The application of input-oriented DEA model for the hospitality sector is mentioned e.g. by Karakitsiou et al. (2018); Horváthová \& Mokrišová (2018); the output-oriented model is used e.g. by 


\section{JOURNAL OF TOURISM AND SERVICES}

Issue 12, volume 22, ISSN 1804-5650 (Online)

www.jots.cz

Poldrugovac et al. (2016). By Samut \& Cafri (2016); Büchner et al. (2016); Marrakchi \& Essid (2019), input-oriented DEA model is more suitable for the health care sector; Mahate et al. (2016); Dénes et al. (2017) consider the output-oriented DEA model to be more suitable. By the authors of this paper, the analysis of technical efficiency should be quantified by means of the input-oriented DEA model, as influencing inputs in the given field is more acceptable and realistic compared to outputs. Another important decision within the specification of a suitable DEA model is choosing from radial or nonradial models. The application of the CCR DEA model in the hospitality sector is preferred e.g. by Tsai et al. (2017); Horváthová \& Mokrišová (2018); Karakitsiou et al. (2018); Higuerey et al. (2020), on the other hand e.g. Poldrugovac et al. (2016); Tsai et al. (2017); Karakitsiou et al. (2018) prefer using the BCC DEA model for efficiency evaluation. In terms of the health care sector, Samut \& Cafri (2016); Papadaki \& Stańková (2016); Szabo et al. (2018) prefer the application of the CCR DEA model, and Sendek et al. (2015); Papadaki \& Staňková (2016); Szabo et al. (2018) prefer the BCC DEA model. On the basis of the analysed research studies, the authors of this paper prefer the application of the BCC DEA model, as it is not possible to assume constant returns to scale in terms of linear increase in outputs when increasing outputs and vice versa.

a) Selecting relevant input and output variables of the model

On the basis of a detailed analysis of the aforementioned empirical studies and subsequent assessment of meeting the conditions of the data completeness and adherence to the steps of proper selection of the input and output variables, correlation analysis is applied, used to verify the final variables within the application of the BCC-I DEA model - three inputs and two outputs. The input variables are the following: the total number of beds (Input_01), total number of employees (Input_02) and the number of medical workers (Input_03); the output variables in the form of indicators are the following: utilization of bed capacity (Output_01) and the number of clients treated (Output_02).

b) Normalization of results to a uniform scale

Scaling of results achieved within the application of selected DEA models to a uniform scale was not necessary, as the quantified efficiency using the programme is at the required interval of $\langle 0,1\rangle$. Even in this case, the higher value reflected the better evaluation and vice versa.

Using a simple average in the case of P\&E_I and the subsequent addition of partial scores for individual dimensions, the resulting overall score of the P\&E model is quantified, ranging at the interval of $<0 ; 3>$.

Figure 2. Results of the correlation analysis

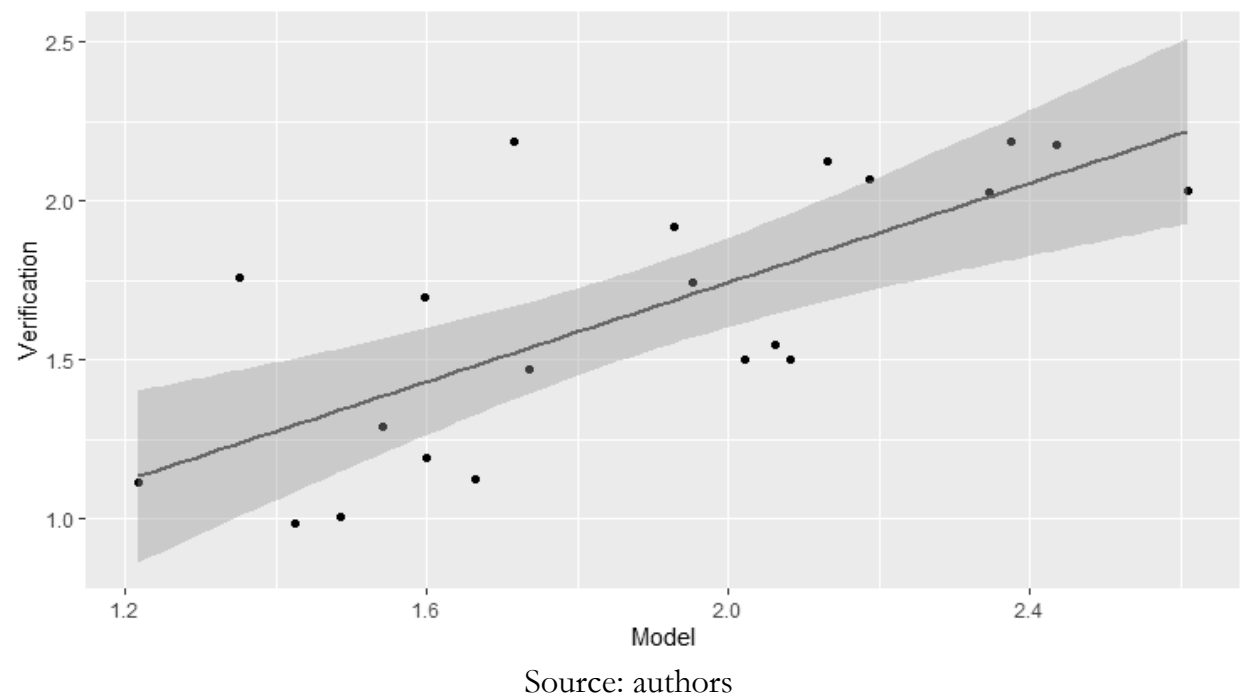

- Verification of the created P\&E model's structure 


\section{JOURNAL OF TOURISM AND SERVICES}

Issue 12, volume 22, ISSN 1804-5650 (Online)

www.jots.cz

Despite the fact that created performance models in Slovak business environment were not verified in any way, the authors of this paper decided to verify the structure of the created P\&E model using correlation analysis. Statistically significant dependence between the average score achieved in the period of 2013 - 2017 is analysed and the average score is quantified identically in 2018.

After confirming that the condition of normal distribution is met, Pearson correlation coefficient is used to determine the intensity of the dependence. At the significance level of $\alpha=0.05$, the achieved p-value is 0.0001969 , which confirms the existence of a statistically significant dependence between the variables (see Figure 2). The value of the correlation coefficient (0.7256) confirms a strong directly proportional dependence between the variables.

The values of the correlation coefficient confirm the suitability of the created P\&E model's structure, although two residuals are identified within the analysis. The deviations are caused by the decrease of the partial score in the case of the dimension P\&E_I in the year 2017 (by 69.55\% on average), especially due to the deterioration of the liquidity and profitability ratios in the enterprises.

\section{Results}

The following partial analyses are focused mainly on the best and worst spa enterprises in comparison with their competitors in the sector. Within the paper, their strengths and weaknesses, characteristics, and development are examined.

\subsection{Dimension P\&E_I}

Within the evaluation of the first dimension of the P\&E model, SE03 shows the best overall financial situation (the specification of different spa enterprises is reported in Chapter 3.1). The second best financial result with the average score of 0.8159 is recorded in SE21. The third best spa enterprise in the period of $2013-2018$ is SE18, with the average score of 0.7230 . The worst average score of the P\&E_I (0.0439) is achieved by SE19, considered the least financially efficient enterprise. In the last three years of the analysed period, the worst ranked enterprise is SE14; however, due to the higher average score $(0.1561)$, it ranked $20^{\text {th }}$ in total. The worst ranked enterprise, with the worst financial situation, is SE09.

The most significant decline within the analysed period is recorded in evaluating the financial situation of SE05, which fell by eleven places from 2013. The second biggest decline (by nine places) is reported in SE17. The enterprise fell from the $8^{\text {th }}$ to the $17^{\text {th }}$ place; its overall competitive position $\left(12^{\text {th }}\right.$ place), however, was threatened by SE02, SE15, and SE10. During 2018, these three enterprises showed the most significant improvement of their financial situation, which strengthened their position and made them the leaders. The third most significant decline within the monitored period (by 7 places) is reported in SE20. Its stable development was disrupted mainly in the years 2016 and 2018.

The enterprises showing the best financial results achieve a dominant position, the highest score within the performance ratios. SE03 is identified as a leader and the benchmark of Slovak spa enterprises in terms of performance shows the best overall results in four assessed areas - liquidity, profitability, cost efficiency, and cash flow. In terms of assessing the level of debt and capital structure, SE03 ranks the second. More acceptable values are achieved by SE21, caused also by its significantly dominant financial position, compared to the other enterprises. One of the best partial results in terms of liquidity and debt is achieved by SE20, which is rated as the $6^{\text {th }}$ (on average). SE04 has the dominant position in terms of profitability and cost efficiency; however, significantly worse results are achieved within the other groups of ratios, so that is rated as the $10^{\text {th }}$.

\subsection{Dimension P\&E_II}




\section{JOURNAL OF TOURISM AND SERVICES}

Issue 12, volume 22, ISSN 1804-5650 (Online)

www.jots.cz

As revealed by the results, the Slovak spa enterprises are not able to generate positive value of EVA. Regarding the investors, the enterprises cannot be considered a profitable investment. An average value of economic loss of all the spa enterprises for the analysed period ranged between $€$ 364,589 (2016) and $€-658,498$ (2014). The average value for the whole analysed period is $€-492,358$. Extreme negative values are caused by low ROE (Return on equity), achieving $2.72 \%$. It does not exceed $r_{e}(7.17 \%)$, which multiplied high equity by negative value. Spa enterprises are thus not able to pay all common costs including the costs related to using the equity and are not able to generate added value for investors.

Based on the achieved results of EVA, the authors proceeded to the calculation of its

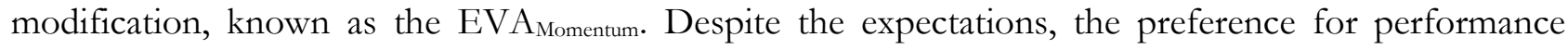
dynamics modified by considering the size of the enterprise through the amount of revenues causes some significant positive changes. The average value of the $\mathrm{EVA}_{\text {Momentum }}$ for all the spa enterprises in the monitored period is between -3.11\% (2014) and 2.43\% (2015). Positively evaluated is the fact that between 2015 and 2017, the average values of the given ratio are positive, although they decrease in the following years and in 2018, they are below zero again. As the size of the enterprise and the volume of

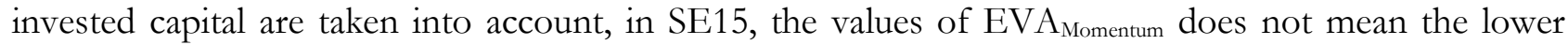
extreme of the sample (unlike the absolute value of EVA).

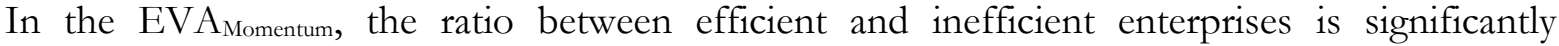
different. Although the positive absolute value of EVA is achieved on average only by three spa

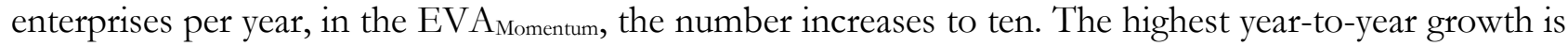
recorded in 2015, when the required dynamics of economic efficiency is achieved by 16 enterprises. The revenues of $€ 1$ are followed by an average year-to-year increase in EVA by 2.43 cents. The average economic loss in the following three years increases faster $(12.53 \%)$ than the revenues $(5.23 \%)$. The entire sector shows a negative development trend with its maximum in 2018. The results revealed that the $\mathrm{EVA}_{\text {Momentum }}$ provides a warning signal on decreasing financial performance of the enterprises in the following period. The development of the number of efficient and inefficient enterprises, based on the $\mathrm{EVA}_{\text {Momentum, is shown in Figure } 3 .}$

\section{Figure 3. Number of enterprises with positive/negative EVA $\mathbf{A}_{\text {Momentum }}$}

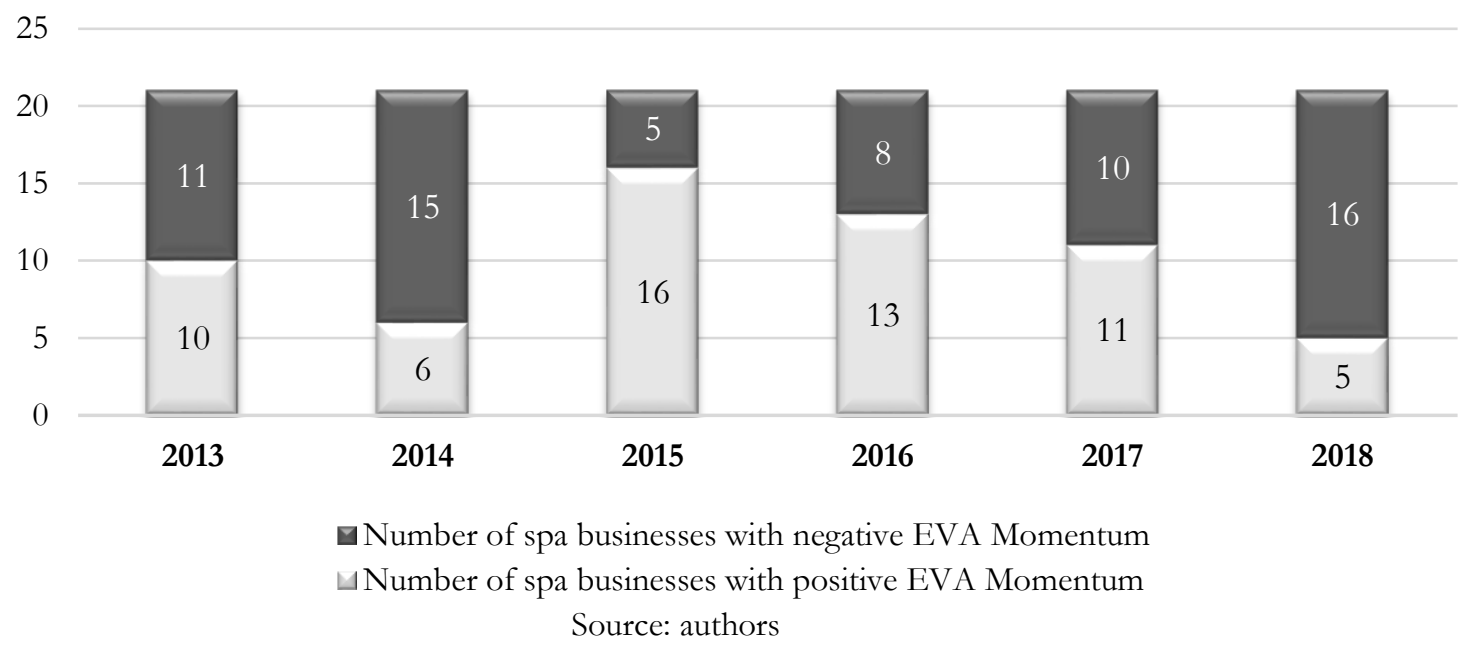

In terms of the dynamic creation of added value, the overall best results are achieved by SE12. Although the enterprise achieves the sector maximum only in 2015 within the analysed period, thanks to its high average score (0.7661), the enterprise is rated $1^{\text {st }}$ in the area of evaluation. With the average score of P\&E_II achieving 0.7489, SE02 is rated $2^{\text {nd }}$ in the ranking despite of the fact that the absolute 


\section{JOURNAL OF TOURISM AND SERVICES}

Issue 12, volume 22, ISSN 1804-5650 (Online)

www.jots.cz

value of EVA is not positive in any year of research. The three enterprises with the best values for the entire analysed period included also SE09, with the average score of 0.7366 .

Within the evaluated dimension P\&E_II, the worst average results are reported in SE19, which is at the last place $\left(21^{\text {st }}\right)$, with the average score of 0.3615 . The second worst average score of P\&E_II (0.3639) is reported in SE05. SE13 is the third least efficient spa enterprise achieving the third lowest average score P\&E_II (0.4900).

\subsection{Dimension P\&E_III}

Although the final structure of the P\&E model includes only the input-oriented DEA model with the assumed variable returns to scale (BCC-I), the authors apply four types of the input and output oriented DEA models with the assumed constant and variable returns to scale on the basis of obtained non-financial data - CCR-I, CCR-O, BCC-I, BCC-O, which are, by the literary research, among the most commonly used DEA models in health care and hospitality sectors. Based on the results, it is reported that the average efficiency score for the application of all aforementioned DEA models is identically identified only in the case of the efficient enterprises - SE16, SE18, SE19, and SE21. The CCR-I and CCR-O models provide rather the same results.

The achieved degree of efficiency of spa enterprises on the basis of BCC-I DEA model does not change significantly during the research. The minimum values range between 0.3724 (2015) and 0.4483 (2013). The development of average values of technical efficiency shows a positive (growing) trend until 2015; however, in the last three years of the research, the year-to-year efficiency decreases by $1.84 \%$. The overall average value for all enterprises and analysed period is 0.7527 , which means that an average spa enterprise would need only $75.27 \%$ of the currently used inputs to achieve the efficiency limit. The maximum efficiency of 1.00 is achieved by several enterprises in the research period, which also reflects the overall situation and development of the efficiency in the sector.

In each year during the research period, the number of inefficient enterprises is higher than the number of efficient enterprises; however, the ratio does not change significantly (see Figure 4). The highest number of efficient enterprises is recorded in 2013 and 2017; however, the following years show the most significant decrease. On average, in spa industry, there are seven efficient enterprises $(33.33 \%)$ and fourteen inefficient enterprises $(66.67 \%)$. The results of the analyses point to the fact that in the analysed years, four out of seven efficient enterprises operate in the conditions of decreasing returns to scale; the remaining three in the conditions of constant returns to scale.

Figure 4. Number of efficient and inefficient enterprises

25

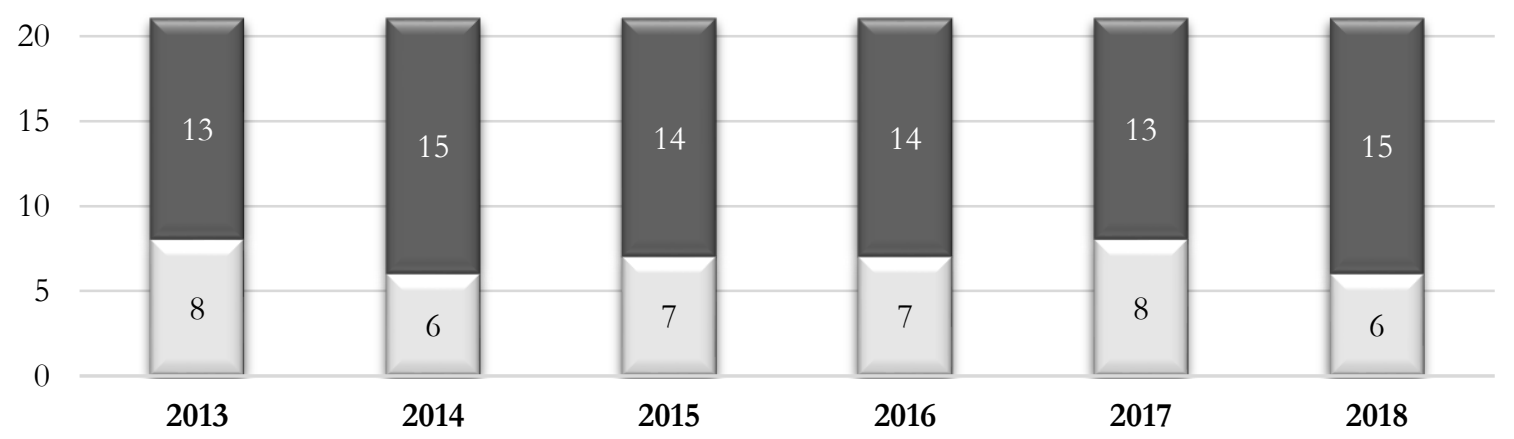

$\square$ Number of efficient spa businesses $\square$ Number of inefficient spa businesses

Source: authors 


\section{JOURNAL OF TOURISM AND SERVICES}

Issue 12, volume 22, ISSN 1804-5650 (Online)

www.jots.cz

In 2013, there is a total of eight spa enterprises in the first place in the ranking (SE03, SE13, SE15, SE16, SE17, SE18, SE19, SE21), although all of them operate to their production limits and the level of their efficiency achieves 1.0000. In the following year, the number of the efficient enterprises decreases to six (SE15, SE16, SE17, SE18, SE19, SE21). In SE03, the efficiency score decreases to 0.9863, mainly due to a disproportionate increase in Input_01. The identical development causes the decrease in the efficiency of SE06 (0.6922), which could then use approximately $30.78 \%$ fewer inputs, thus reaching the required efficiency limit. However, the situation improves in the following years (2015 - 2017), and SE06, followed by SE20 in 2017, joins the stable leaders. In 2017, the first place was again occupied by eight spa enterprises; however, the above-mentioned enterprises are not able to stabilize their position in the following year.

In terms of the position of different spa enterprises over time, no change is recorded for SE11, SE15, SE16, SE17, SE18, SE19, and SE21. Except for SE11, the remaining efficient enterprises are considered a model for the inefficient enterprises in the sector, thus helping them to manage their resources (inputs) more efficiently. The positive development between 2015 and 2017 causes the improved position of SE06, as mentioned previously. The most significant drop is recorded in SE13 and SE03.

\subsection{Overall competitive position of spa enterprises}

This subchapter is focused on summarizing the previous partial results. On the basis of the overall score of the P\&E model, given by the addition of all the partial scores for different dimensions (P\&E_I, P\&E_II, and P\&E_III), the final rating of Slovak spa enterprises is revealed for 2013 - 2018.

The results reported in Table 1, together with the previous partial evaluations show that SE03 is a clear benchmark of the Slovak spa enterprises, as it achieves the highest sector score of the P\&E model in the years 2013, 2014, and 2016; it is rated $2^{\text {nd }}$ in 2015 and in the last two analysed years, it is the $6^{\text {th }}$ on average. However, it shall be noted that the deviations in the score are not significantly different; therefore, it is not recommended to assess the position of enterprises solely on the basis of ranking. Although the overall average score of the P\&E model for the years 2013 - 2018 (2.51) significantly exceeds the score of other enterprises, its competitive position is slightly weaker over the years.

Regarding the total P\&E model score, SE21 is the second strongest benchmark in the sector of Slovak spa business. Although the enterprise does not achieve the sector maximum in any year of the analysed period, it operates at the limit of its production possibilities each year, using its resources effectively, with positive financial results. In 2013 - 2018, the three most efficient spa enterprises on the basis of the created P\&E model include SE18, reaching the average score of 2.34. The enterprise manages to become a leader in the sector in the 2017, mainly due to a significant improvement of its financial results together with the dynamics of generating economic profit. On the other hand, SE14, SE09, and SE19 are the weakest enterprises in Slovak spa business. Their partial scores within the dimensions of the P\&E model point to the significant shortcomings in all assessed areas. The only exceptions are the maximum level of technical efficiency in SE19, and rather high values of $\mathrm{EVA}_{\text {Momentum }}$ in SE09. These enterprises are recommended to consider their current situation in detail and focus on following the enterprises with the best competitive position in the industry.

Considering the development trend of the overall score of the P\&E model in the case of individual spa enterprises, the most significant positive change is reported in SE02 and SE10, as their score increased on average by $6 \%$, improving their position in the ranking by up to nine places. Besides the above-mentioned enterprises (SE02 and SE10), the most significant strengthening of competitive position is reported in SE01 (four places), SE05, SE06 (three places), SE07 (two places), and SE14, SE18, SE19 (one place). The position of SE04 and SE15 is not changed. On the contrary, the most 


\section{JOURNAL OF TOURISM AND SERVICES}

Issue 12, volume 22, ISSN 1804-5650 (Online)

www.jots.cz

significant drop reflecting weakening of the position in the sector is reported in SE13 (six places), SE03, SE17, SE20 (five places), SE11, SE16 (three places), SE08, SE09 (two places), and SE12, SE21 (one place). In conclusion, the position of the enterprises in $2013-2018$ is rather stable, without any significant deviations and fluctuations.

Table 1. Development of P\&E total score

\begin{tabular}{|c|c|c|c|c|c|c|c|c|c|c|}
\hline \multirow{2}{*}{ Enterprise } & \multicolumn{6}{|c|}{ Total score of P\&E model in the years } & \multirow{2}{*}{$\begin{array}{c}\text { Average } \\
\text { rating }\end{array}$} & \multicolumn{3}{|c|}{$\begin{array}{l}\text { Average score of P\&E model for } \\
\text { the dimensions }\end{array}$} \\
\hline & 2013 & 2014 & 2015 & 2016 & 2017 & 2018 & & P\&E_I & P\&E_II & P\&E_III \\
\hline SE03 & 2.81 & 2.95 & 2.32 & 2.70 & 2.26 & 2.03 & 1. & 0.9829 & 0.6682 & 0.8340 \\
\hline SE21 & 2.67 & 2.66 & 2.15 & 2.38 & 2.31 & 2.18 & 2. & 0.8159 & 0.5750 & 1.0000 \\
\hline SE18 & 2.59 & 2.63 & 1.83 & 2.25 & 2.58 & 2.19 & 3. & 0.7230 & 0.6205 & 1.0000 \\
\hline SE16 & 2.42 & 2.30 & 2.45 & 2.55 & 2.01 & 2.02 & 4. & 0.6301 & 0.6620 & 1.0000 \\
\hline SE15 & 2.33 & 2.34 & 1.97 & 2.08 & 2.21 & 2.07 & 5. & 0.5623 & 0.6043 & 1.0000 \\
\hline SE07 & 2.30 & 2.20 & 1.65 & 2.21 & 2.29 & 2.12 & 6. & 0.6675 & 0.6946 & 0.7770 \\
\hline SE06 & 1.74 & 2.09 & 2.28 & 2.19 & 2.13 & 1.50 & 7. & 0.5080 & 0.5998 & 0.9316 \\
\hline SE17 & 2.25 & 2.48 & 1.70 & 2.03 & 1.84 & 1.54 & 8. & 0.4743 & 0.5004 & 1.0000 \\
\hline SE20 & 2.11 & 2.21 & 1.68 & 1.68 & 2.43 & 1.50 & 9. & 0.6047 & 0.5460 & 0.7971 \\
\hline SE01 & 1.99 & 1.98 & 1.97 & 1.68 & 2.03 & 1.92 & 10. & 0.5932 & 0.6292 & 0.7030 \\
\hline SE08 & 2.19 & 2.05 & 1.40 & 2.13 & 1.99 & 1.74 & 11. & 0.5640 & 0.5896 & 0.7537 \\
\hline SE02 & 2.06 & 1.99 & 1.95 & 1.51 & 1.07 & 2.19 & 12. & 0.4457 & 0.7498 & 0.5907 \\
\hline SE04 & 1.75 & 1.78 & 1.29 & 2.18 & 1.69 & 1.47 & 13. & 0.5224 & 0.6366 & 0.5497 \\
\hline SE05 & 1.75 & 1.24 & 1.53 & 1.37 & 2.08 & 1.70 & 14. & 0.4743 & 0.3639 & 0.7630 \\
\hline SE12 & 1.66 & 1.60 & 1.61 & 1.81 & 1.63 & 1.12 & 15. & 0.3071 & 0.7661 & 0.5037 \\
\hline SE13 & 2.06 & 2.01 & 1.36 & 1.67 & 0.90 & 1.19 & 16. & 0.3342 & 0.4800 & 0.6599 \\
\hline SE11 & 1.77 & 1.68 & 1.23 & 1.58 & 1.44 & 1.29 & 17. & 0.4622 & 0.6240 & 0.4016 \\
\hline SE10 & 1.66 & 1.84 & 0.88 & 1.78 & 0.60 & 1.76 & 18. & 0.4127 & 0.5059 & 0.4987 \\
\hline SE19 & 1.09 & 1.63 & 1.14 & 1.70 & 1.87 & 1.01 & 19. & 0.0439 & 0.3615 & 1.0000 \\
\hline SE09 & 1.64 & 1.81 & 1.29 & 1.34 & 1.04 & 0.99 & 20. & 0.1575 & 0.7366 & 0.4562 \\
\hline SE14 & 1.42 & 1.74 & 0.76 & 0.63 & 1.53 & 1.11 & 21. & 0.1561 & 0.4900 & 0.5706 \\
\hline
\end{tabular}

Source: authors

\section{Discussion}

The model-based assessment of performance and efficiency of the enterprises operating in tourism is the subject of any professional studies especially by the foreign authors. However, Altin et al. (2018) state that not sufficient attention has been paid to this issue; in their study, they tried to emphasize the necessity making any progress in the field. By the authors, the current systems of measuring performance of the enterprises in tourism lack a generalized internal structure and defined uniform performance criteria applicable in the context of the international comparison. This fact is also dealt with by Sainaghi et al. (2017), whose detailed analysis of 978 research studies conducted between 1996 and 2014 contributes to deepening the knowledge on the systems of measuring performance of tourism companies. In its conclusion, the authors suggest the key areas and the most important dimensions of corporate performance that would be decisive for further research trends in the next decade. 


\section{JOURNAL OF TOURISM AND SERVICES}

Issue 12, volume 22, ISSN 1804-5650 (Online)

www.jots.cz

The research on the efficiency of the enterprises operating in tourism is addressed in the studies by many authors. Corne \& Peypoch (2020) use a two-stage efficiency analysis, combining the DEA method and qualitative comparative analysis with a fuzzy set. The result is the efficiency model for the emprises in tourism, emphasizing the multiple effects of the determinants. By Oltean \& Gabor (2020), for increasing corporate performance, the application of services quality management (Androniceanu, 2017 ) is important, influencing the performance of hotels and emphasizes the specifics of the enterprises operating in tourism. The research by Kitsios \& Grigoroudis (2020) focuses on performance of the enterprises in tourism. It determines the importance of financial liquidity for the efficiency of business, i.e. the ability of the enterprise to use available resources to achieve specific sales goals. The variables mentioned above may determine how fast and efficiently the assets convert to cash. Performance of the enterprises in tourism is addressed also by Li Sa et. al. (2020). Their research shows that there is a direct relation between customer orientation and performance of the enterprise; the initiatives of customer orientation influence the process of creating corporate knowledge, which depends on the dynamic abilities of the owners and managers of the tourism enterprises.

In most research studies, the efficiency level of enterprises operating in health tourism is analysed mainly using different variants and modifications of the DEA method, also used when choosing suitable metrics for creating the P\&E model. For the purposes of comparison, several research studies are used, focusing on analysing the efficiency of enterprises operating in tourism, especially health tourism, hospitality, and hospital facilities analysis included in the spa business sector. For example, Androutsou \& Metaxax (2019) use the DEA model and conclude that the high efficiency score is achieved mainly by the enterprises providing care for the clients visiting spa for relaxation and rest. Regarding the enterprises providing medical care, especially to the outpatients, their efficiency score achieves significantly lower values. In their study, Papadaki \& Staňková (2016) focus on comparing the efficiency level of hospital facilities providing spa care also. Based on the application of the BCC DEA model, the authors do not confirm the assumption that those facilities in private ownership achieve higher efficiency score than facilities owned by state, town, or district; however, their study contributes significantly to formulating specific possibilities of improving the efficiency of different facilities.

Lo Storto \& Goncharuk (2017) carries out an extensive study comparing the systems of health care in 32 European countries using the CCR DEA model in the years 2011 - 2014. Based on its results, the authors conclude that the national systems of health care in the countries under review achieve a significantly different level of efficiency, which changes unevenly over time. The authors also suggest applying a two-dimensional approach to evaluate effectiveness in terms of efficiency and intensity, as they are interrelated and they have effect on the total score. Such approach may help the policy makers to identify shortcomings of the systems and justify the need for their reform. By the results of the study, the lowest efficiency is reported in health facilities in Ukraine, Bulgaria, Switzerland, Latvia, and Romania.

Samut \& Cafri (2016) carry out a study evaluating the efficiency of hospital facilities in the OECD countries using input-oriented DEA model in 2000 - 2010. In addition to the analysis of yearto-year changes using Malmquist index, the author analyse the factors that positively and negatively affect the efficiency of the facilities under review, which, however, need to be further specified for a specific country. The output-oriented DEA model to evaluate the efficiency of rehabilitation facilities is applied by Dénes et al. (2017). By the authors, the application of this type of DEA model in facilities providing any form of health care should be preferred, as the reduction of inputs in providing health care is in principle undesirable and the demand for health care services has a growing trend rather than decreasing. In the conclusion of their study, the authors emphasize the differences in the efficiency of different departments and they identify the weaknesses that caused such significant differences.

In the hospitality sector, which partly falls under the analysed tourism sector (i.e. providing spa care for the purposes of relaxation and rest), several authors, such as Tsai et al. (2017); Karakitsiou et al. 


\section{JOURNAL OF TOURISM AND SERVICES}

Issue 12, volume 22, ISSN 1804-5650 (Online)

www.jots.cz

(2018); Higuerey et al. (2020) apply the DEA model to evaluate the efficiency of hotels. Higuerey et al. (2020) apply the CCR DEA model on a sample of 147 enterprises classified into different classes and geographical location (in 2013-2017) to examine whether the hotels use the resources optimally. The authors conclude that the highest efficiency is achieved by hotels in the third class, where tourist attractions and activities in their vicinity have a significant impact on the results achieved. The authors thus recommend reconsidering or change the current business strategies of the hotels according to specific regions and market size and focus on better utilization of the production factors.

Despite the effort to summarize similar research studies conducted in Slovak business environment (for the purpose of better comparability of the results achieved), the authors of this paper conclude that the Slovak academics are more and more focused solely on creating predictive models, while performance models are absent. The only model that deals with connecting corporate performance and efficiency evaluation is the HGN model by Hyránek et al. (2014). The model was created in the period of 2010 - 2012 on a sample of 233 Slovak non-financial institutions operating in various industries and regions in Slovakia. From all analysed financial indicators, six ratios are used divided into two equal groups of efficiency and performance ratios. The authors verify the optimal intervals of the created synthetic indicators by applying linear programming; after several modifications, they define three scales - weak, average, and good performance. The authors thus create the first performance model in order to evaluate and also partially predict the future performance and yield potential of Slovak enterprises. However, the application of this HGN performance and efficiency model for Slovak spa enterprises would not be relevant. Therefore, the authors of this paper want to overcome this limitation and deepen the knowledge on performance and efficiency of Slovak spa industry, as it is considered to be the main product line of Slovak tourism.

In this context, it shall be noted that the issue of Slovak spa industry is not addressed by many researchers (Gúčik et al., 2016; Šenková, 2017; Kerekeš 2018). Those authors, however, do not examine the financial performance of efficiency of spa enterprises; they primarily focus their general characterization, importance, strengths and weaknesses, position in the context of Europe, their financing, history of their development, current trends, future orientation, etc. Nevertheless, all of them point to the constantly growing importance of the spa industry and spa tourism in connection with the increasing awareness in the field of caring for their own health and healthy lifestyle. They also perceive the unexploited potential of the country in this attractive industry, which should be paid greater attention to given the existing possibilities and unstoppable globalization process. Financial situation of Slovak spa enterprise is (at least partially) analysed in the studies by Derco \& Pavlišinová (2016). They also deal with the quality of spa procedures leading to the increase in therapeutic and wellness stays and the importance of public health insurance for occupancy of accommodation facilities.

Derco (2017) follows the results of the above-mentioned study and analyse the impact of the payment method for spa care (self-payers, health insurers) on the financial position and stability of the Slovak spa facilities in 2013 - 2016, based on three financial ratios: ROA, revenue growth rate, and the ratio of net profit. The author conclude that the financial stability of spas is based on the balance between the two groups of clients mentioned above; the stagnant volume of revenues is one of the main factors that are the cause of significantly below-average (even critical) financial results in most spa enterprises. The assessment of financial position of the Slovak spa facilities using the multidimensional methods and subsequently multidimensional scaling is addressed e.g. by Litavcová, et al. (2018). The basic evaluation criteria are the following financial ratios - ROA, ROS, the share of personnel costs in sales, and the share of value added on net turnover.

A similar study is conducted by Jenčová et al. (2019) for 2013 - 2017.The financial-economic analysis of the spa enterprises is carried out, using four methods (ranking method, scoring method, standardized variable method, and the method of distance from a fictitious object) with the use of the same financial ratios of the performance and efficiency as in the above-mentioned study. By the results, the best position within the monitored period is achieved by the following spa enterprises: Spa Bojnice, 


\section{JOURNAL OF TOURISM AND SERVICES}

Issue 12, volume 22, ISSN 1804-5650 (Online)

www.jots.cz

Inc., Spa Lúčky, Inc., Spa Dudince, Inc., Spa Bardejov, Inc. and Slovak Thermal Spa Piešt’any, Inc. To sum up, by applying the proposed P\&E model, it is possible to achieve comparable results and almost identically identify the strongest competitors and the leaders in the Slovak spa industry.

\section{Conclusion}

Based on the results of practical application of the newly designed P\&E model, it could be concluded that SE03 (Spa Bojnice, Inc.) is the benchmark for Slovak spa enterprises, followed by SE21 (Specialised Spa Institute Marína, s.e.) and SE18 (Spa Horný Smokovec, Ltd.). The most significant strengthening of the competitive position is reported in SE02 (Horezza, Inc.) and SE10 (Spa Štós, Inc.), as their score increased on average by $6 \%$ in the research period and their position in the ranking moved up by up to nine places. The weakest position within the analysed spa enterprises is reported in SE14 (Natural Iodine Spa Č́žz, Inc.), SE09 (Spa Sliač, Inc.), and SE19 (Pieniny Resort, Ltd.). Their partial score within the dimensions of the P\&E model indicates the existence of some significant shortcomings in all evaluated areas. In general, the position of the spa enterprises in $2013-2018$ is rather stable and no significant deviations or fluctuations are reported.

The submitted paper is beneficial in particular in terms of deepening the knowledge on measuring and management of corporate efficiency and performance using the multi-criteria models in Slovak business environment. The results of the practical application of the models are supposed to be used as a basis for further analysis of the factors that affect efficiency and performance of business in the spa industry and in other areas of tourism and other industries. The developed methodology of creating the structure of the P\&E model and the quantification of the total score are possible to be used as the basis for creating new or modified models for other sectors of Slovak economy. An important thing is to reassess the suitability of the internal factor structure of the variables within the P\&E_I dimension, to modify sectoral $\beta_{\text {Levered }}$ when calculating $r_{\mathrm{e}}$ using the CAPM model, to consider the selection of a specific DEA model and its inputs and outputs. When analysing other period, it is necessary to adjust the tax rate and the input parameters of the CAPM model.

The research revealed the results applicable for the business entities both in the spa industry and in other industries. From a practical point of view, it is necessary to consider the factors such as the size of the spa enterprise and its current financial situation. An important practical benefit is the definition of market position of the spa enterprise and the identification of its major competitors and their comparison. By the authors, the proposed model is possible to be applied in neighbouring countries, if the countries operate under similar conditions and have undergone a similar development of the economy.

An important practical benefit of the paper is especially the evaluation of the overall financial situation, the ability to generate added value for shareholders, and to achieve the required level of technical efficiency in the Slovak spa enterprises in 2013 - 2018. The research also enables the enterprises to compare the achieved performance and efficiency with the competitors in the spa industry, based on the rating of the total score of the P\&E model in 2013 - 2018. The results also show the strengths and weaknesses of the Slovak spa enterprises after considering their position in partial rating within P\&E_I, P\&E_II, and P\&E_III dimensions. An important benefit of the study, however, is the identification of the strongest competitor in the Slovak spa industry, known as the benchmark, based on which other spa enterprises should assess their position and its working experience might be an inspiration.

The most significant limitation of the presented study is the size of the research sample, which could not be influenced in any way due to the number of the enterprises actively operating in the area of spa health care. However, this fact is considered through the use of the appropriate mathematicalstatistical method. Another limitation of the study is related to the limited data provided for the non- 


\section{JOURNAL OF TOURISM AND SERVICES}

Issue 12, volume 22, ISSN 1804-5650 (Online)

www.jots.cz

financial variables included in the DEA model. Not all analysed spa enterprises kept records of the required data; therefore, they had to be excluded from further analyses due to incomplete data. If other variables were selected in combination with another type of the DEA model, different results would probably be achieved. The last limitation in the creation of the P\&E model is its verification. The possibilities of verifying the structure of this model are considerably limited due to its unique structure and the specificity of the research sample. It is thus impossible to compare the results with the results of other similar performance models and to verify the model. At the same time, it is not possible to determine the training and testing sample of enterprises.

The aforementioned limitations of the study also represent suggestions for further research. It would be interesting to include spa enterprises from other European countries in the analyses and to find out how the position of the Slovak spa industry as well as the rating of individual Slovak spa enterprise will change in the context of international comparison. The authors intend to further analyse and modify the created model and include other dimensions of business activity (e.g. competitiveness, risk, sustainable development), to choose relevant methods; develop the method for their calculation, thus contributing to the improvement of its complexity. The created P\&E model is to be applied in other industries with necessary modifications, thus contributing to the expansion of its application in practice. Each sector has its own way of functioning and the models for evaluating efficiency and performance can be set differently in different sectors.

\section{Acknowledgments}

This research was funded by Technology Agency of the Czech Republic, programme of ETA, project reg. no. TL02000215 - Digital Transformation for Business Model Innovations in Small and Medium Sized Enterprises in the Czech Republic.

\section{References}

1. Altin, M., Köseoglu, M., A., Yu, X. \& Riasi, A. (2018). Performance Measurement and Management Research in the Hospitality and Tourism Industry. International Journal of Contemporary Hospitality Management, 30(2), 1172-1189. doi: 10.1108/IJCHM-05-2017-0251

2. Androniceanu, A. (2017). The Three-Dimensional Approach of Total Quality Management, an Essential Strategic Option for Business Excellence. Amfiteatru Economic, 19(44), 61-78. Retrieved February 15, 2021, from https://www.econstor.eu/handle/10419/169057

3. Androniceanu, A. (2020). Major Structural Changes in the EU Policies due to the Problems and Risks Caused by COVID-19. Administratie si Management Public, 34, 137-149. doi: $\underline{10.24818 / \mathrm{amp} / 2020.34-08}$

4. Androutsou, L., \& Metaxas, T. (2019). Measuring the Efficiency of Medical Tourism Industry in EU Member States. Journal of Tourism Analysis: Revista de Análisis Turistico, 26(2), 115-130. doi: 10.1108/JTA-02-2019-0006

5. Balogová, M., Šarišská. M. \& Hamadej, M. (2020). Slovak Adolescents' View of the Persons Serving an Alternative Sentence. Ad Alta-Journal of Interdisciplinary Research, 10(2), 285-288. Retrieved October $\quad 25, \quad 2020, \quad$ from http://www.magnanimitas.cz/ADALTA/1002/papers/A sarisska.pdf

6. Belás, J., Khuramm, A. K., Maroušek, J. \& Rozsa, Z. (2020). Perceptions of the Importance of Business Ethics in SMEs: A Comparative Study of Czech and Slovak Entrepreneurs. Ethics and Bioethics (in central Europe), 10(1-2), 96-106. doi: 10.2478/ebce-2020-0010 


\section{JOURNAL OF TOURISM AND SERVICES}

Issue 12, volume 22, ISSN 1804-5650 (Online)

www.jots.cz

7. Bhasin, M. L. (2017). A Study of Economic Value Added Disclosures in the Annual Reports: Is EVA a Superior Measure of Corporate Performance. East Asian Journal of Business Economics, 5(1), 10-26. doi: 10.20498/eajbe.2017.5.1.10

8. Blažková, I. \& Dvouletý, O. (2018). Sectoral and firm-Level Determinants of Profitability: A Multilevel Approach. International Journal of Entrepreneurial Knowledge, 6(2), 32-44. doi: 10.2478/IJEK-2018-0012

9. Büchner, V. A., Hinz, V. \& Schreyögg, J. (2016). Health Systems: Changes in Hospital Efficiency and Profitability. Health Care Management Science, 19(2), 130-143. doi: 10.1007/s10729014-9303-1

10. Callender, G. (2012). Efficiency and Management. Abingdon: Taylor \& Francis Group.

11. Contreras, I. (2019). A Review of the Literature on DEA Models Under Common Set of Weights. Journal of Modelling in Management, 15(4), 1277-1300. doi: 10.1108/JM2-02-2019-0043

12. Corne, A. \& Peypoch, N. (2020) On the Determinants of Tourism Performance. Annals of Tourism Research, 85, 103057. doi: 10.1016/i.annals.2020.103057

13. Dénes, R. V., Kecskés, J., Koltai, T. \& Dénes, Z. (2017). The Application of Data Envelopment Analysis in Healthcare Performance Evaluation of Rehabilitation Departments in Hungary. Quality Innovation Prosperity, 21(3), 127-142. doi: 10.12776/qip.v21i3.920

14. Derco, J. \& Pavlišinová, D. (2016). Financial Position of Medical Spas - The Case of Slovakia. Tourism Economics, 23(4), 867-873. doi: 10.5367/te.2016.0553

15. Derco, J. (2017). Impact of Health Care Funding on Financial Position of Slovak Medical Spas. Tourism: An International Interdisciplinary Journal, 65(3), 376-380. Retrieved October 23, 2020, from https://hrcak.srce.hr/186960

16. Draskovic, M., Draskovic, V., Bilan, Y. \& Delibasic, M. (2016). Quasi-Neoliberalism as Quasi Institutional Monisms and Causes of the Crisis in South-Eastern Europe. Transformations in Business and Economics, 15(2), 755-765. Retrieved February 24, 2021, from http://www.transformations.knf.vu.lt/38b/article/quas

17. Dokulil, J., Popesko, B., \& Dvorský, J. (2020). The budgeting processes of czech companies: The role of the ownership structure and foreign capital. Oeconomia Copernicana, 11(4), 779-798. doi: 10.24136/OC.2020.031

18. Drossos, D. \& Tsotsolas, N. (2014). Customer Satisfaction Evaluation for Greek Online Travel Agencies. Evaluating websites and web services: Interdisciplinary perspectives on user satisfaction, 119-137. doi: 10.4018/978-1-4666-6543-9.ch050

19. Emrouznejad, A. \& Yang, G. L. (2018). A Survey and Analysis of the First 40 Years of Scholarly Literature in DEA: 1978 - 2016. Socio-Economic Planning Sciences, 2018(6), 4-8. doi: 10.1016/i.seps.2017.01.008

20. Eremina, Y., Lace, N. \& Bistrova, J. (2019). Digital Maturity and Corporate Performance: The Case of the Baltic States. Journal of Open Innovation: Technology, Market, and Complexity, 5(3), 1-13. doi: 10.3390/joitmc5030054

21. Faltejsková, O., Dvořáková, L. \& Hotovcová, B. (2016). Net Promoted Score Integration into the Enterprise Performance Measurement and Management System - A Way to Performance Methods Development. $E+M$ Ekonomie a Management, 19(1), 93-107. doi: 10.15240/tul/001/2016-1-007

22. Farrell, M. J. (1957). The Measurement of Productive Efficiency. Journal of the Royal Statistical Society, Series A, 120(3), 253-290. doi: $10.2307 / 2343100$

23. Fernando, I. N. (2020). Tourism Competitiveness by Shift-Share Analysis to Way-forward Destination Management: A Case Study for Sri Lanka. Journal of Tourism and Services, 21(11), 88102. doi: $10.29036 /$ jots.v11i21.139 


\section{JOURNAL OF TOURISM AND SERVICES}

Issue 12, volume 22, ISSN 1804-5650 (Online)

www.jots.cz

24. Gallo, P. \& Mihalčová, B. (2016). Knowledge and Use of the Balanced Scorecard Concept in Slovakia related to Company Proprietorship. Quality - Access to Success, 17(151), 64-68. Retrieved October 26, 2020, from https://www.srac.ro/calitatea/en/arhiva/2016/2016-02-Abstracts.pdf

25. Ganesha, H. S., Vaswani, L. K. \& Subudhi, R. N. (2020). Applications of DEA. International Journal of Innovative Technology and Exploring Engineering, 8(12), 3337-3341. doi: $\underline{10.35940 / \text { ijitee.L2829.1081219 }}$

26. Gorochnaya, V. V., Mikhaylov, A. S., Mikhaylova, A. A. \& Plotnikova, A. P. (2020). Tourism Clusters and Innovation Security: Dialectics in the Western Border Regions of Russia. GeoJournal of Tourism and Geosites, 28(1),127-139. doi: 10.30892/gtg.28110-457

27. Gruenbichler, R., Klucka, J., Haviernikova, K., \& Strelcova, S. (2021). Business Performance Management in Small and Medium-Sized Enterprises in the Slovak Republic: An Integrated Three- Phase-Framework for Implementation. Journal of Competitiveness,13(1), 42-58. doi: $10.7441 /$ joc. 2021.01 .03

28. Gúčik, M., Kvasnová, D. \& Pančíková K. (2016). Medical Spa Versus Health Tourism. Acta Academica Karviniensia, 16(2), 5-15. Retrieved October 23, 2020, from http://aak.slu.cz/pdfs/aak/2016/02/01.pdf

29. Gupta, V. K. \& Sikarwar, E. (2016). Value Creation of EVA and Traditional Accounting Measures: Indian Evidence. International Journal of Productivity and Performance Management, 65(4), 436-459. doi: 10.1108/IJPPM-01-2014-0008

30. Haseeb, M., Hussai, H. I., Kot, S., Androniceanu, A. \& Jermsittiparsert, K. (2019). Role of Social and Technological Challenges in Achieving a Sustainable Competitive Advantage and Sustainable Business Performance. Sustainability, 11(14), Article Number: 3811. doi: $10.3390 /$ su11143811

31. Herman, G. V., Wendt, J. A., Dumbravă, R. \& Gozner, M. (2019). The Role and Importance of Promotion Centers in Creating the Image of Tourist Destination: Romania. Geographia Polonica, 92(4), 443-454. doi: 10.7163/GPol.0158

32. Higuerey, A., Viňan-Merecí, CH., Malo-Montoya, Z. \& Martínez-Fernández, V. A. (2020). Data Envelopment Analysis (DEA) for Measuring the Efficiency of the Hotel Industry in Ecuador. Sustainability, 12(4), 1-18. doi: 10.3390/su12041590

33. Horváthová, J. \& Mokrišová, M. (2018). Risk of Bankruptcy, Its Determinants and Models. Risks, 6(4), 1-22. doi: 10.3390/risks6040117

34. Hyránek, M., Grell, E. \& Nagy, L. (2014). Nové trendy merania výkonnosti podniku pre potreby finančných rozhodnutí. Bratislava: Ekonóm.

35. Charnes, A., Cooper, W. W. \& Rhodes. E. (1978). Measuring the Efficiency of DecisionMaking Units. European Journal of Operational Research, 2(6), 429-444. doi: 10.1016/03772217(78)90138-8

36. Choong, K. K. (2013). Understanding the Features of Performance Measurement System: A Literary research. Measuring Business Excellence, 17(4), 102-121. doi: 10.1108/MBE-05-2012-0031

37. Jenčová, S., Vašaničová, P. \& Petruška, I. (2019). Financial Position of the Slovak Spa Companies. Paper presented at the conference of European Financial Systems 2019: Proceedings of the $16^{\text {th }}$ International Conference, Brno, Czech Republic.

38. Karakitsiou, A., Kourgiantakis, M., Mavrommati, A. \& Migdalas, A. (2018). Regional Efficiency Evaluation by Input-Oriented Data Envelopment Analysis of Hotel and Restaurant Sector. Operational Research, 24, 1-18. doi: 10.1007/s12351-018-0406-1

39. Ključnikov, A., Popesko, B., \& Kloudová, J. (2019). Economics of the international ridesharing services-a trap for amateurs. Entrepreneurship and Sustainability Issues, 6(3), 1172-1181. doi: 10.9770/jesi.2019.6.3(8) 


\section{JOURNAL OF TOURISM AND SERVICES}

Issue 12, volume 22, ISSN 1804-5650 (Online)

www.jots.cz

40. Ključnikov, A. \& Belás, J. (2016). Approaches of Czech Entrepreneurs to Debt Financing and Management of Credit Risk. Equilibrium. Quarterly Journal of Economics and Economic Policy, 11(2), 343-365. doi: 10.12775/EQUIL.2016.016

41. Kelić, I., Erceg, A. Čandrlić \& Dankoš, I. (2020). Increasing Tourism Competitiveness: Connecting Blue and Green Croatia. Journal of Tourism and Services, 20(11), 132-149. doi: 10.29036/jots.v11i20.138

42. Kerekeš, J. (2018). Kúpelníctvo a jebo význam v turiz̨me. Bratislava: Weltprint.

43. Kiryluk, H., Glińska, E., \& Barkun, Y. (2020). Benefits and Barriers to Cooperation in the Process of Building a Place?s Brand: Perspective of Tourist Region Stakeholders in Poland. Oeconomia Copernicana, 11(2), 289-307. doi: 10.24136/oc.2020.012

44. Kitsios, F. C. \& Grigoroudis, E. (2020). Evaluating Service Innovation and Business Performance in Tourism: A Multicriteria Decision Analysis Approach. Management Decision, 58(11), 2429-2453. doi: 10.1108/MD-09-2019-1326

45. Kostynets, I., Kostynets, V., \& Baranov V. (2020).Pent-up Demand Effect at the Tourist Market. Economics and Sociology, 13(2), 279-288. doi: 10.14254/2071-789X.2020/13-2/18

46. Kotane, I. (2015). Evaluating the Importance of Financial and Non-Financial Indicators for the Evaluation of Company's Performance. Management Theory and Studies for Rural Business and Infrastructure Development, 37(1), 80-94. doi: 10.15544/mts.2015.08

47. Kozubikova, L., Kotaskova, A., Dvorsky, J. \& Kljucnikov, A. (2019). The Impact of Political Factors' Perception Onsuitability of International Business Environment: The Case of Startups. Economics and Sociology, 12(1), 61-79. doi: 10.14254/2071-789X.2019/12-1/3

48. Kumbhakar, S. C., Wang, H. J. \& Horncastle, A. P. (2015). A Practitioner's Guide to Stochastic Frontier Analysis Using Stata. New York: Cambridge University Press.

49. Li Sa, M. L., Choon-Yin, S., Chai, Y. K. \& AikJoo, J. H. (2020). Knowledge Creation Process, Customer Orientation and Firm Performance: Evidence from Small Hotels in Malaysia. Asia Pacific Management Review, 25(2), 65-74. doi: 10.1016/j.apmrv.2019.07.002

50. Litavcová, E., Jenčová, S., Košíková. M. \& Šenková, A. (2018). Implementation of Multidimensional Analytical Methods to Compare Performance Between Spa Facilities. Paper presented at the conference of International Days of Statistics and Economics: Conference proceedings, Prague, Czech Republic.

51. Lo Storto, C. \& Goncharuk, A. G. (2017). Efficiency vs Effectiveness: A Benchmarking Study on European Health Care Systems. Economics and Sociology, 10(3), 102-115. doi: 10.14254/2071789X.2017/10-3/8

52. Mahate, A., Hamidi, S. \& Akinci, F. (2016). Measuring the Effect of Size on Technical Efficiency of the United Arab Emirates Hospitals. Global Journal of Health Science, 9(3), 116-127. doi: $10.5539 /$ gjhs.v9n3p116

53. Marrakchi, M. D. \& Essid, H. (2019). Efficiency Assessment of Tunisian Public Hospitals Using Data Envelopment Analysis (DEA). Economic Research Forum, Working Paper No. 1291, 1-27. Retrieved October 10, 2020, from https://erf.org.eg/publications/efficiency-assessmentof-tunisian-public-hospitals-using-data-envelopment-analysis-dea-2/

54. Mura, L. (2020). Marketing Management of Family Businesses: Results of Empirical Study. International Journal of Entrepreneurial Knowledge, 8(2), 56-66. doi: 10.37335/ijek.v8i2.118

55. Narkuniené, J. \& Ulbinaite, A. (2018). Comparative Analysis of Company Performance Evaluation Methods. Entrepreneurship and Sustainability Issues, 6(1), 125-138. doi: 10.9770/jesi.2018.6.1(10)

56. Nikšić Radić, M., Dragičević, D. \& Barkiđija Sotošek, M. (2018). The Tourism-Led Terrorism Hypothesis - Evidence from Italy, Spain, UK, Germany and Turkey. Journal of International Studies, 11(2), 236-249. doi: 10.14254/2071-8330.2018/11-2/16 


\section{JOURNAL OF TOURISM AND SERVICES}

Issue 12, volume 22, ISSN 1804-5650 (Online)

www.jots.cz

57. Oladimeji, M. S., Eze, B. U. \& Akanni, K. A. (2018). Business Eco System and Micro, Small and Medium Enterprises (MSMES) Performance in Nigeria. International Journal of Entrepreneurial Knowledge, 6(1), 76-86. doi: 10.2478/ijek-2018-0006

58. Oltean, F. D. \& Gabor, M. R. (2020). Service Quality Management and Hotel Performance Particularities from Romanian Hospitality Industry: A Complex Statistical Analysis. Quality Access to Success, 21(179), 91-100. Retrieved February 25, 2021, from https://www.researchgate.net/publication/341398216 Service quality management and hote lperformance particularities from Romanian hospitality industry a complex statistical analysis

59. Papadaki, Š. \& Staňková, P. (2016). Comparison of Horizontally Integrated Hospitals in Private and Public Sectors of Czech Republic. Economics and Sociology, 9(3), 180-194. doi: 10.14254/2071-789X.2016/9-3/16

60. Poldrugovac, K., Tekavcic, M. \& Jankovic, S. (2016). Efficiency in the Hotel Industry: An Empirical Examination of the Most Influential Factors. Economic Research, 29(1), 583-597. doi: 10.1080/1331677X.2016.1177464

61. Popesko, B., Ključnikov, A., Hrabec, D., \& Dokulil, J. (2016). Predictability of business environment within budgeting process - is it connected with fluctuations of economy? Economics and Sociology, 9(2), 90-100. doi: 10.14254/2071-789X.2016/9-2/6

62. Ruinan, L. (2019). Comparison of Bank Efficiencies between the US and Canada: Evidence Based on SFA and DEA. Journal of Competitiveness, 11(2), 113-129. doi: 10.7441/joc.2019.02.08

63. Šambronská, K., Matušíková, D., Gallo, P., Šenková, A. \& Mitríková, J. (2016). Hotel Services Quality Base of Dimension of Service. Paper presented at the conference of Political Sciences, Law, Finance, Economics and Tourism: $3^{\text {rd }}$ International Multidisciplinary Scientific Conference Social Sciences \& Arts SGEM 2016, Albena, Bulgaria.

64. Sainaghi, R., Phillips, P. \& Zavarrone, E. (2017). Performance Measurement in Tourism Firms: A Content Analytical Meta-Approach. Tourism Management, 59(2017), 36-56. doi: 10.1016/j.tourman.2016.07.002

65. Sakdanuwatwong, P. (2020). The Role of Employees' Perception of Corporate Social Responsibility and Employee Trust on Perceived Corporate Performance for Sustainable Firm. Polish Journal of Management Studies, 22(1), 470-484. doi: 10.17512/pims.2020.22.1.30

66. Samut, P. K. \& Cafri, R. (2016). Analysis of the Efficiency Determinants of Health Systems in OECD Countries by DEA and Panel Tobit. Social Indicator Research, 129(1), 113-132. doi: 10.1007/s11205-015-1094-3

67. Sekhon, A. K. \& Kathuria, L. M. (2019). Analyzing the Impact of Corporate Social Responsibility on Corporate Financial Performance: Evidence from Top Indian firms. Corporate governance, 20(1), 143-157. doi: 10.1108/CG-04-2019-0135

68. Sendek, S., Svitálková, Z. \& Angelovičová, K. (2015). Efficiency Evaluation of Hospitals in the Environment of the Czech and Slovak Republic. Acta Universitatis Agriculturae et Silviculturae Mendelianae Brunensis, 63(6), 2109-2118. doi: 10.11118/actaun201563062109

69. Šenková, A., Šambronská, K., Mitríková, J., Matušíková, D. \& Mat’ková, S. (2016). Corporate Culture as a Tool for Increasing Employee Motivation. Polish Journal of Management Studies, 13(2), 131-141. doi: 10.17512/pjms.2016.13.2.13

70. Šenková, A. (2017). Kúpelnictvo a kúpel’ný cestovný ruch na Slovensku. Prešov: Prešovská univerzita v Prešove.

71. Shad, M. K., Lai, F. W., Fatt, C. L., Klemeš, J. J. \& Bokhari, A. (2019). Integrating Sustainability Reporting into Enterprise Risk Management and its Relationship with Business Performance: A Conceptual Framework. Journal of Cleaner Production, 208, 415-425. doi: $\underline{10.1016 / \text { i.j.jepro. } 2018.10 .120}$ 


\section{JOURNAL OF TOURISM AND SERVICES}

Issue 12, volume 22, ISSN 1804-5650 (Online)

www.jots.cz

72. Šip, Maroš. 2018. Die Lebensqualität eines Individuums im Terminalsstadium der Krankheit. Pieknie jest byc starszym: o starosci interdyscyplinarnie. Proceedings of the Miedzynarodowa Sesja Naukowa: Dusapasterstwo parafialne wobec osób starszych - wspótczesne wyzwania, Kraków, Poland, 15th-16th May.

73. Schwab, L., Gold, S. \& Reiner, G. (2019). Exploring Financial Sustainability of SMEs during Periods of Production Growth: A Simulation Study. International Journal of Production Economics, 212, 8-18. doi: 10.1016/j.ijpe.2018.12.023

74. Štefanová, M. \& Balogová, B. (2019). Sociálne experimenty v prepojení na nový trend v manažmente-Talent manažment. Journal socioterapie, 5 (3). 11-24. Retrieved February 22, 2021, from $\quad$ https://www.unipo.sk/public/media/29623/Jornal $\% 20$ socioterapie $\% 203 \% 20$ $\% 202019 . p d f$

75. Stichhauerova, E. \& Pelloneova, N. (2019). An Efficiency Assessment of Selected German Airports Using the DEA Model. Journal of Competitiveness, 11(1), 135-151. doi: $10.7441 /$ ioc. 2019.01 .09

76. Strelnik, E. U., Usanova, D. S., Khairullin, I. G., Shafigullina, G. I. \& Khairullina, K. T. (2017). Key Performance Indicators in Internal Control. Journal of Engineering and Applied Sciences, 12(19), 4899-4904. Retrieved October 15, 2020, from https://medwelljournals.com/abstract/?doi=jeasci.2017.4899.4904

77. Szabo, S., Mihalčová, B., Gallo, P. \& Ivaničková, M. (2018). Evaluating Efficiency in Specialized Hospital Facilities - Developing the Model by Way of the Discriminant Analysis. $E+M$ Ekonomie a Management, 21(3), 88-106. doi: 10.15240/tul/001/2018-3-006

78. Tovmasyan, G. (2020). Evaluating the Quality of Hotel Services Based on Tourists' Perceptions and Expectations: The Case Study of Armenia. Journal of International Studies, 13(1), 93-107. doi: 10.14254/2071-8330.2020/13-1/6

79. Tsai, H., Liu, H. \& Wu, J. (2017). Performance Assessment of Hong Kong Hotels. Joumal of China Tourism Research, 13(2), 123-140. doi: 10.1080/19388160.2017.1340859

80. Van der Schyff, T., Meyer, D. \& Ferreira, L. (2019). An Analysis of Impact of the Tourism Sector as a Viable Response to South Africa's Growth and Development Challenges. Journal of International Studies, 12(1), 168-183. doi: 10.14254/2071-8330.2019/12-1/11

81. Wnuczak, P. (2018). Social Value Added (SVA) as an Adaptation of Economic Value Added (EVA) to the Specificity of Cultural Institutions. Journal of Management and Business Administration, 26(1), 100-120. doi: 10.7206/imba.ce.2450-7814.221

82. Zhang, J. \& Aboud, A. (2019). Determinants of Economic Value Added (EVA) in Chinese Listed Banks. Asian Review of Accounting, 27(4), 595-613. doi: 10.1108/ARA-11-2018-0216

83. Zhou, H., Yang, Y., Chen, Y. \& Zhu, J. (2018). Data Envelopment Analysis Application in Sustainability: The Origins, Development and Future Directions. European Journal of Operational Research, 265(1), 1-16. doi: 10.1016/j.ejor.2017.06.023

\section{Brief description of Authors:}

\section{Mgr. Veronika Čabinová, PhD.}

ORCID ID: https://orcid.org/0000-0003-4367-3590

Department of Development, Informatization and Quality Assessment, Rectorate, University of Prešov in Prešov, 17 ${ }^{\text {th }}$ November 15, 08001 Prešov, Slovakia, www.unipo.sk, veronika.cabinova@unipo.sk. The author's publishing activity is focused on the issue of multi-criteria concepts of evaluation and management of business performance and efficiency, financial and economic analysis, financial management, business economics, modern management tools of business management and international evaluation of the competitiveness of countries. 


\section{Ing. Peter Gallo, PhD.}

ORCID ID: https://orcid.org/0000-0001-5193-1997

Institute of Educology and Social Work, Faculty of Arts, University of Prešov in Prešov, $17^{\text {th }}$ November 1, 08001 Prešov, Slovakia, www.unipo.sk, peter.gallo.1@unipo.sk. The author's publishing activity is focused on the issue of strategic management, human resources management, managerial tools in the field of tourism, managerial decisions in social companies, talent management, and gender stereotypes in society.

\section{Ing. Petra Pártlová, PhD.}

ORCID ID: https://orcid.org/0000-0003-2404-6073

Department of Management, Faculty of Corporate Strategy, Institute of Technology and Business in České Budějovice, Okružní 517/10, 37001 České Budějovice, Czech Republic, www.is.vstecb.cz, 4027@mail.vstecb.cz. The author's publishing activity focuses on strategic management, tax problematics in Slovak and Czech Republic and distribution logistics, business plans and innovations, and management in the tertiary sphere.

\section{doc. Ing. Ján Dobrovič, PhD.}

ORCID ID: https://orcid.org/0000-0002-0637-106X

Department of Management, Faculty of Corporate Strategy, Institute of Technology and Business in České Budějovice, Okružní 517/10, 37001 České Budějovice, Czech Republic, www.is.vstecb.cz, 24574@mail.vstecb.cz. The author's publishing activity focuses on strategic management, tax problematics in Slovak and Czech Republic and distribution logistics, business plans and innovations, and management in the tertiary sphere.

\section{Ing. Milan Stoch, PhD.}

ORCID ID: https://orcid.org/0000-0002-5290-7136

Institute of Entrepreneurship and Management, University of Entrepreneurship and Law, Prague, Czech Republic, www.vspp.cz, 100ch@centrum.cz. The author's current publishing activity is focused on the issue of innovativeness of the SMEs, enterprise ownership patterns, business performance, and efficiency in the tourism sector. 